\title{
La Patria visualizada
}

\author{
Guillermo de la Peña
}

ENRIQUE FLORESCANO, 2005

\section{Imágenes de la patria a través de los siglos}

Taurus, Secretaría de Cultura del Gobierno de Michoacán, México, mapas, ilustraciones, $488 \mathrm{pp}$.

$A \begin{aligned} & \text { lo largo de su carrera, el histo- } \\ & \text { riador Enrique Florescano }\end{aligned}$ ha tenido un tema favorito: el de las construcciones conceptuales y las imágenes de la realidad mexicana. Esta fascinación lo llevó a promover en la década de 1970 un conjunto de seminarios sobre las historiografías de nuestro país, en los que forjaron sus armas intelectuales un buen número de jóvenes historiadores y antropólogos. Años después, Florescano publicaría —entre otrostres libros que sintetizan y vuelven accesible su extenso conocimiento historiográfico: Memoria mexicana (1987 y 2001), Memoria indígena (1999) e Historia de las historias de la nación mexicana (2002). Pero el interés de este autor ha ido mucho más allá de la memoria escrita: se dirige también a la memoria visual y a la construcción de imágenes simbólicas de la patria; por ello, nos entregó un estudio de La bandera de México (1998), compiló la obra Espejo mexicano (2002), y ahora vuelve a la lid con esta obra comprensiva, ambiciosa,

\section{A View of the Nation}

GUILLERMO DE LA PEÑa: Centro de Investigaciones y Estudios Superiores en Antropología Social-Occidente, Guadalajara, México.

gdelapen@ciesasoccidente.edu.mx

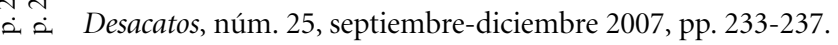

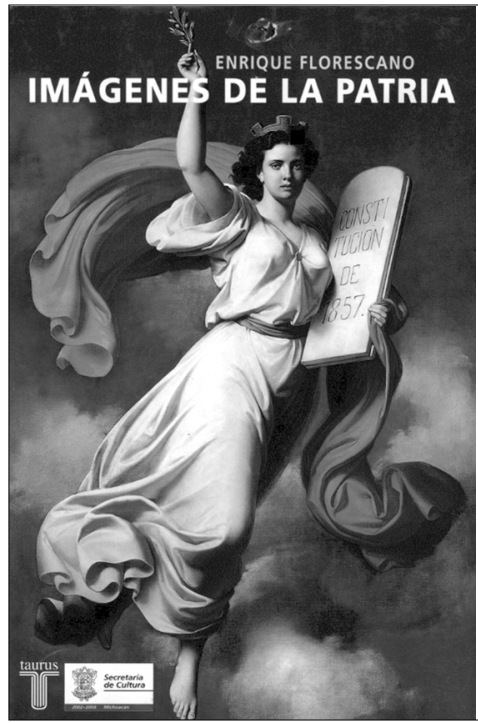

magníficamente ilustrada y escrita con fluidez, que da cuenta de la forja imaginaria de la nación. Una de sus premisas, ya planteada en trabajos anteriores, es que las fuentes de la historia no están sólo en los archivos escritos, sino también en los mitos, la tradición oral y la plástica tanto "culta" como popular.

Imágenes de la patria... debe entenderse en el contexto de una magna 
controversia acerca del surgimiento y la naturaleza de la nación, de sus transformaciones y crisis, y de su posible desaparición. Desde los orígenes de esta controversia aparecen dos posiciones opuestas: la romántica y la modernista. La romántica, que se remonta a los tratados de Herder y Fichte, resalta el papel de los impulsos emocionales -incluso telúricos- en la constitución de una cultura distintiva expresada en tradiciones y símbolos populares que, a su vez, determina la persistencia de una identidad colectiva. La posición modernista, en cambio, nutrida del pensamiento de la Ilustración y del positivismo, destaca el pacto racional que hace que un vasto conjunto de individuos encuentre una forma adecuada de organizarse en un territorio dado. Para los modernistas, "el plebiscito de todos los días" de que hablaba Renan es lo que permite que nos refiramos a la nación como una realidad; pero esta realidad sólo tiene sentido en la búsqueda racional de mejores normas para la vida cotidiana, y conduce necesariamente a un Estado cada vez más metódico y centralizado. Ciertos autores recientes, como Ernest Gellner, hacen hincapié en la fuerza detonante de la revolución capitalista industrial en los procesos de formación nacional. Es decir: el predominio de la tecnología industrial en el proceso de acumulación volvió necesaria la movilidad de la fuerza de trabajo y la comunicación entre localidades físicamente distantes; en consecuencia, propició el surgimiento de un Estado que no sólo monopolizara la fuerza legítima para regular el orden público, sino que además impusiera una cultura nacional homogénea y un sentido de pertenencia a grupos históricamente dispersos y heterogéneos en sus lenguas y costumbres. El nacionalismo y la identidad nacional, por tanto, según Gellner, nada tienen que ver con "las fuerzas telúricas", sino con la capacidad de los grupos dirigentes para responder a exigencias históricas traídas por la extensión de la ciencia y la tecnología y la concomitante transformación del trabajo social. (Esta es la historia que nos ha narrado, por ejemplo, Eugen Weber en su libro titulado, significativamente, De campesinos a franceses.)

Junto a estas dos posturas en principio opuestas, se ha desarrollado una tercera en autores como Benedict Anderson y Anthony Smith, que podríamos caracterizar como constructivismo histórico. En ella se admite el papel centrípeto del Estado que responde a los cambios del capitalismo industrial mediante leyes y políticas unificadoras, que a su vez conducen a la consolidación de burocracias racionalizadas, la exclusión de la Iglesia de la política, la regulación de los grupos religiosos, la creación de un ejército nacional estrictamente jerarquizado y de un servicio militar obligatorio y, de manera eminente, la escolarización, la capacitación técnica y la difusión de lecturas impresas en una lengua común. Sin embargo, se reconoce también que en este proceso de creación de unidad no se puede hacer tabla rasa de la historia ni de las identidades y los símbolos emocionales existentes; por el contrario: es menester incorporarlos. Lo que crea sentido de pertenencia no es "el fulgor abstracto" de la patria racionalizada, que diría José Emilio Pacheco, sino más bien "la suave patria, alacena y pajarera”, de Ramón López Velarde, donde pueden acogerse y anidarse las historias de los diferentes grupos. Alfonso Reyes hablaba de la continuidad de "la emoción compartida ante el mismo paisaje"; pero esa emoción existe cuando el paisaje se inserta en una metanarrativa y en una metaimagen que lo vincula al pasado y lo hace habitable y defendible por todos. Los sentimientos localistas y las afiliaciones particularistas no ceden ante el nacionalismo si éste no los incorpora en nuevas "tradiciones inventadas" que vuelvan aceptable la convergencia. Es la dialéctica entre la patria y las matrias historiadas y celebradas por Luis González y González. Como lo ha recalcado Claudio Lomnitz, el Estado nacional, para serlo, expropia los mitos y los emblemas de los lugares, las regiones y las etnias y los dota de un sentido innovador en estructuras simbólicas inclusivas, que los compatibilizan y, al mismo tiempo, los subordinan.

El libro de Enrique Florescano que aquí comentamos se sitúa críticamente en esta tercera postura de constructivismo histórico: explora cómo ciertas imágenes emocionalmente cargadas, que cambian a lo largo de la historia mexicana, han buscado representar las identidades colectivas $y$, a partir del siglo XVIII, la totalidad de una nación emergente. Así, se nos introduce, en el primer capítulo, a una serie de representaciones de deidades femeninas que en los albores de la historia humana, en México como en otras muchas partes del mundo, alu- 
den a la vez a la fertilidad generosa de la tierra y a la solidaridad igualitaria del mundo tribal por ella alimentado. Después, la aparición de sociedades estratificadas gobernadas por guerreros y sacerdotes conllevó representaciones de deidades masculinas. En el México precolombino, en la época clásica y posclásica, la identidad colectiva ya se vincula claramente a un territorio - llamado altépetl en lengua náhuatl— que se simboliza en una montaña y en una pirámide; ésta, a su vez, representa la existencia de grupos dominantes y grupos dominados. Sin embargo, la figura femenina y maternal en cuanto emblema incluyente no desaparece. Tras la Conquista, resurgirá como la Virgen de Guadalupe. Todavía entre ciertos grupos indígenas del México actual, como los huicholes y los coras, las diosas abuelas y diosas madres, dadivosas y protectoras, nos remiten a significados de un parentesco mítico que permite la unidad de todos. A través del tiempo, la Tonantzin náhuatl o la Joven Águila wixárika encontrarían acomodo como Guadalupe, el ícono maternal de indios, criollos y mestizos, plasmado también en los estandartes de los movimientos que han querido fundar o replantear la identidad mexicana, como los de los insurgentes, los zapatistas y los chicanos.

En el mundo azteca encontramos una clase gobernante que tenía la voluntad explícita de reescribir la historia de una vasta colectividad y representarla con símbolos a la vez inteligibles y sobrecogedores que suscitaran simultáneamente sentimientos de pertenencia y obediencia, adhesión y terror. Esta sociedad nacional embrionaria se vio dislocada por la Conquista. Poco a poco, la identidad colectiva de quienes fueron nombrados indios se redujo al mundo de sus comunidades corporadas. Florescano nos muestra, en el capítulo 2, cómo a partir del siglo XVI las imágenes de la sociedad americana se elaboraron desde Europa, al representarla gráficamente como una bella mujer indígena pródiga en dones o, alternativamente, como una figura salvaje y peligrosa. Por otro lado, ya en el siglo XVII empiezan a aparecer imágenes generadas por los nuevos americanos - los criollos y los mestizos- - y en el siglo XVIII la Virgen de Guadalupe se convierte en un ubicuo emblema patriótico, con sus facciones y ropajes mestizos. Y una atención especial merecen del autor las llamadas pinturas de castas, que más allá de retratar, no sin ironía, la índole jerárquica de la sociedad colonial, muestran un mundo multicultural e intercomunicado, cuya principal valía está precisamente en la variedad de las clases populares. Esto se revela con más fuerza en cuadros como el que pintó Villalpando, de la espléndida plaza mayor de México, donde se ofrecían mercancías de todo tipo y una sociedad dinámica y variopinta observaba la entrada del virrey a su palacio (p. 89). Llama también la atención un cuadro bellísimo e inusitado, en el que todas las castas se unen bajo el patrocinio de Guadalupe (p. 79). Habría que recordar que la mentalidad barroca, dominante en la Nueva España del XVIII, se vinculaba con la idea de la importancia de los sentidos en la adquisición del conocimiento y la contemplación de la verdad. El patriotismo criollo no era sólo un movimiento político: era, también, una nueva sensibilidad vinculada con una nueva plástica.

La Independencia trajo una mezcla interesante y bizarra de imágenes aztecas —el águila y la serpiente_criollo-mestizas — de nuevo la Virgen de Guadalupe y las alegorías de la patria nueva como mujer criolla o a veces mestiza-, e incluso imitaciones escenográficas de los fastos napoleónicos. Tanto los artistas académicos —extranjeros algunos de ellos- como los anónimos del pueblo retrataron positivamente los heterogéneos tipos populares mexicanos, enmarcados en escenarios urbanos bulliciosos o en paisajes rurales de asombrosa belleza y vastedad (cap. 3). Sin embargo, comenzaron a surgir representaciones subversivas, hechas por grabadores y caricaturistas, en las que la patria aparecía como un águila famélica y desplumada o como una mujer apaleada, víctima de las guerras civiles, las invasiones extranjeras y los gobernantes corruptos e ineptos. Tras el triunfo de la República federal vino una época triunfalista, plena de imágenes gloriosas del liberalismo y la reforma (cap. 4).

Muchos próceres liberales favorecían una concepción modernista de la patria, que dejara de lado el barroquismo religioso colonial y se ciñera, si acaso, a una severa esquematización visual de los ideales republicanos. Por ello se puso de moda pintar gorros frigios, y se repetía la imagen de una mujer (blanca), modelada en la Marianne de la Revolución Francesa, que 


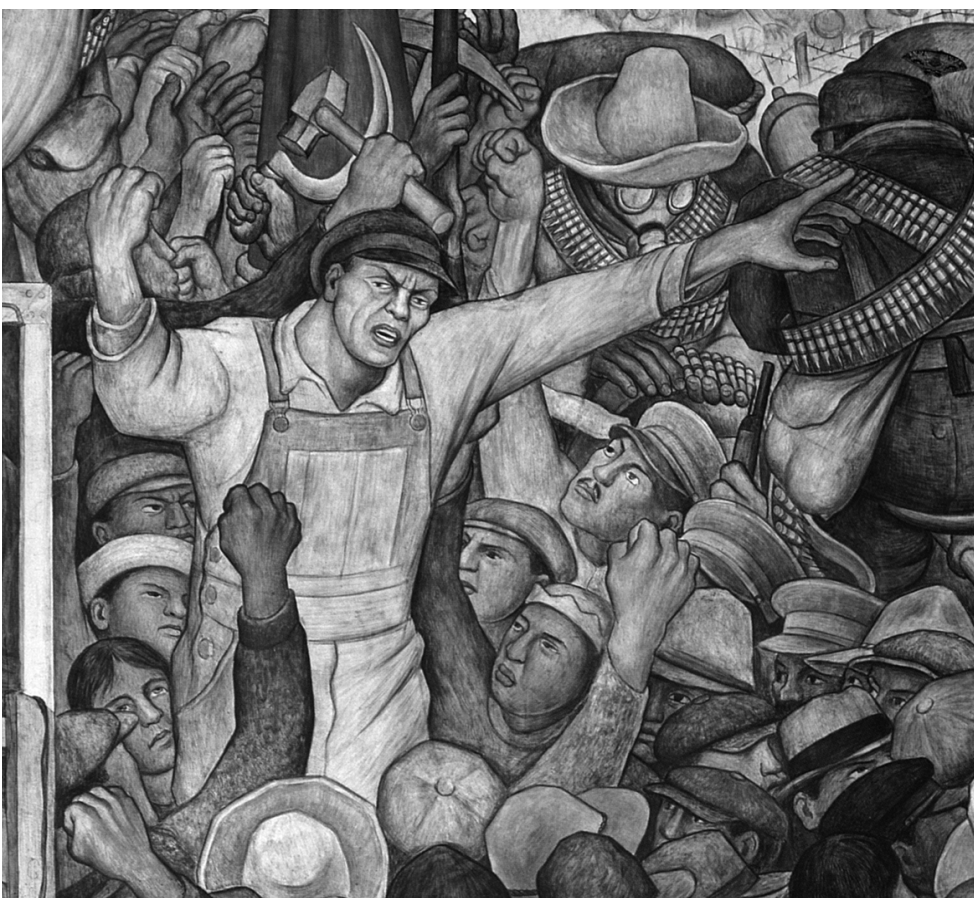

Diego Rivera, México hoy y mañana. Obrero arengando a las masas (detalle), 1934-1935.

empuñaba la Constitución, representada como las tablas de Moisés. Pero lo que ocurrió más acusadamente, sobre todo durante la dictadura porfirista (cap. 5), fue una proliferación de imágenes de héroes: desde los guerreros prehispánicos que se opusieron a la Conquista hasta los líderes de la Independencia y la Reforma. Se quiso reemplazar el panteón de los santos católicos por otro de santos republicanos; así, el mayor santo era Benito Juárez, cuya efigie se multiplicó. La historia nacional se volvió una "historia de bronce" (para usar otra expresión de Luis González): una sucesión de estatuas tiesas. El héroe más deslumbrante en sus retratos, ampliamente glorificado en vida, fue quien desde 1876 ejercía el poder: Porfirio
Díaz. Las fiestas del centenario celebraban la patria próspera y pacífica, pero también la apoteosis personal del dictador. En el contexto de tal celebración se dio una transfiguración del mundo prehispánico, visto como una civilización de belleza clásica, tan difunta como la civilización grecolatina. Florescano nos recuerda que los grandes excluidos de este mundo triunfalista eran los indios vivos y los herederos de los conservadores. Deberían añadirse a la lista las clases trabajadoras mestizas. Curiosamente, en las páginas que el autor dedica a la República Restaurada y el Porfiriato no se incluyen las visiones plásticas de la patria generadas por la oposición (incluida la liberal). Por ejemplo, las caricaturas de El Ahuizote, rescatadas y publicadas hace poco por Rafael Barajas "El Fisgón”, arrojaban representaciones muy poco halagüeñas de los próceres, y enseñaban a leer una historia alternativa.

Los capítulos 6, 7 y 8 nos introducen al fascinante mundo de los gobiernos del nacionalismo revolucionario, que explícitamente buscaron transformar la sensibilidad y el pensamiento de los mexicanos mediante un bombardeo a su imaginación. En el muralismo que domina la plástica nacional desde 1920 a 1950 se crea una nueva metanarrativa del país: los protagonistas de la historia no son "los héroes" sino los indios, los trabajadores mestizos, las milicias insurgentes, los chinacos de la Reforma, los ejércitos campesinos de la Revolución y los maestros, escritores y artistas que surgen de ella.

Un poco antes del muralismo - $y$ de la Revolución-, en los dibujos de José Guadalupe Posada, en la pintura de Saturnino Herrán y en la poesía de Ramón López Velarde, había reaparecido un México popular y provinciano, dramático y entrañable, ajeno a los fastos porfiristas. Junto con el muralismo, la nueva clase política — cuyo dirigente conceptual era José Vasconcelos, desde la Secretaría de Educación Pública por él fundada - promovió una definición romántica de la patria, que erigía las manifestaciones musicales, verbales y plásticas de la gente común como "arte nacional". Florescano señala, al lado de los artistas y los maestros, a los antropólogos indigenistas como actores responsables ("intelectuales orgánicos", diría Gramsci) de las transformaciones en la imagi- 
nación nacional. El indigenismo tenía dos tendencias. Buscaba, por un lado, la amalgama de lo indígena y lo europeo en una cultura nacional rica y vigorosa - "no volver indígenas a los mexicanos sino mexicanizar a los indígenas", diría Lázaro Cárdenas-y, por otro, proclamaba el respeto al mundo indígena y la admiración por sus valores sociales y creativos. La segunda tendencia prevaleció en las décadas de 1920 y 1930 y condujo a que el descubrimiento de las culturas indígenas no redundara simplemente en su expropiación en museos nacionales sino en la apertura del Estado hacia sus expresiones propias - artísticas, lingüísticas e incluso políticas-, cuya plausibilidad y vigor se ponían de manifiesto por las investigaciones de los antropólogos. Incorporadas en múltiples lenguajes, las expresiones indígenas alimentaron el surgimiento de un arte moderno, original e inconfundible, que se asumía como mexicano y universal. Empero, este arte emblemático no era homogéneo: sus raíces se hundían en las contrastantes regiones del territorio nacional.

Imágenes de la patria... no muestra las figuraciones nacionales que promovían los opositores al régimen revolucionario (¿no tenían visiones patrióticas los anarquistas, los cristeros o los sinarquistas?). Pero el autor sí presenta la vertiente autoritaria del régimen y la contribución a ella de ciertos intelectuales de izquierda, así como sus controversias y pugnas con pensadores y artistas de talante liberal.

En el capítulo 9 se nos presenta una imagen sumamente crítica de la trans- formación gubernamental en la segunda mitad del siglo XX, cuando el discurso del nacionalismo popular se había degradado en buena medida: expresaba más una autojustificación cínica que un compromiso auténtico con la igualdad social. El arte público recuperó el culto de los héroes como forjadores de la unidad nacional. Se pintaba a los líderes revolucionarios como colaboradores armónicos, cuando en la vida real fueron enemigos acérrimos. El aprecio por los monumentos arqueológicos y las expresiones vernáculas —en la plástica, la música, el cine- se vinculaba a la promoción turística. Los edificios fastuosos y las ceremonias brillantes se trastocaban, en la publicidad de los programas gubernamentales, en emblemas de poder y clientelismo. De particular dureza son los párrafos dedicados por Enrique Florescano al conformismo de muchas universidades y centros de investigación, más interesados en defender sus intereses corporativos que en ahondar en el conocimiento crítico de la realidad nacional y de sus representaciones colectivas. La crisis del régimen que se proclamaba heredero de la Revolución, y los cambios consecuentes en los gobiernos, pusieron de manifiesto la banalidad del nuevo discurso mitológico del nacionalismo popular. En los últimos quince años, éste parece diluirse, pero sólo para ser reemplazado por una mayor confusión en las palabras y las imágenes: los gobiernos llamados neoliberales no parecen saber cuál es la nación que quieren, ni cómo figurarla. Es más esperanzadora, en cambio, la visión del autor sobre los movimientos indígenas que buscan la revitalización de sus culturas y formas de representación política en una nación plural, participativa e incluyente; una nación que, más allá de los planteamientos románticos, modernistas o constructivistas, pueda concebirse, edificarse e imaginarse mediante el diálogo entre los diversos grupos sociales que la conforman.

Este libro, en suma, cumple con el propósito innovador de incitar a pensar la historia de la nación mediante las imágenes creadas por los gobernantes y los actores sociales de distinta índole, aunque concede más espacio a las creaciones visuales de las élites políticas y sus epígonos. Sólo de pasada se menciona a una figura omnipresente en la plástica y en la lírica vernácula, que bien podría pensarse como un símbolo nacional: la Muerte (la Calavera, la Catrina de Posada). No obstante, Enrique Florescano nos conduce con mano segura a través de un sinnúmero de imágenes; sintetiza las interpretaciones que de ellas se han dado y ofrece las suyas propias, siempre interesantes, aunque el lector contemplativo puede realizar a su vez una labor hermenéutica. La inquietante polisemia de la historia, entonces, se torna más evidente. Expreso, por último, dos deseos para futuras ediciones: que se nos proporcione más información sobre la ubicación de las esculturas, pinturas, dibujos y emblemas varios que en esta obra se reproducen, y que se dé mayor cabida a las representaciones críticas y minoritarias de la nación. 